\title{
Is the Other Elsewhere? \\ Culture as a Dialectic of Identities in Driss Chraibi's Mother Spring
}

\section{Yaw OTENG}

\section{I}

n Chraïbi's novel, culture is an arena of competing identities. These various identities that dialectically inform cultural community also The Moroccan writer who presently lives in France rethinks the dual notions of the Self and the Other normally conceptualized and examined in polarized manichaean terms. In Mother Spring, Maghrebian culture is imaginatively recreated not only with reference to French colonization and islamization of indigenous cultures but also in connection with tribal differences and wars. Culture and identity are, therefore, re-examined within the pre-colonial, colonial and post-colonial spaces and through these three temporal sites, marginality becomes a dialectical space where cultural renewal takes place. It is this idea in the novel that one captures through the image of the border used by Homi Bhabha as the domain of cultural performance:

The borderline work of culture demands an encounter with 'newness' that is not part of the continuum of past and present. It creates a sense of the new as an insurgent act of cultural translation. Such art does not merely recall the past as social cause or aesthetic precedent; it renews the past, refiguring it as a contingent 'in-between' space, that innovates and interrupts the per- 
formance of the present. The 'past-present' becomes part of the necessity, not the nostalgia of living. The Location of Culture, 7 The nostalgia that stifles the present and the past that gives credibility to the cultural present are problematized in Mother Spring. In this historical novel, Chraibi uses the literary text as an arena where he contests cultural purity and monologism. From the pre-colonial past where tribes fight each other to the present era where cultures are continuously westernized, through the era of Arabization of Berber culture, Driss Chraïbi discusses the discursive plurality of Maghrebian identity. Through this interconnection of identities, he emphasizes the communal aspect of culture as well as the identity differences that inform the cultural space as a whole.

Narrating the story of a Berber community and the (trans)formations of Maghrebian culture, Chraibi situates the first section of his book in the twentieth century and the second section in 700 A.D. In these two sections, the novelist confronts the Berber with his own other as well as the voices of Arabic and Western others. In this way, otherness, whether internal or external, denies homogeneity and purity of culture and demystifies any unilateral claims to origins of identity. This is depicted through the agonistic co-existence of the Ait Yafelman tribe on the banks of the Oum-er-Bia, a river whose name becomes the title of the book, Mother Spring.

The story of this indigenous tribe before the advent of Arabic culture constitutes the pivotal narrative structure through which Chraïbi demonstrates the ways in which this small community is related to the larger Berber community scattered all over the Maghreb. Although united by language, the Berbers are distinctly differentiated through diverse cultural practices in the novel. The Ait Yafelman and the Far'oun are two Berber tribes who share certain identical cultural traits but differ as far as other cultural characteristics are concerned. If the Far'oun construct their houses using stones, the Aït Yafelman use clay to build theirs. The cock, a quasi-sacred animal for the Ait Yafelman tribe does not carry any sacredness within the Far'oun's cultural space. Insofar as these cultural practices and taboos are concerned, the Far'oun and the Aitt Yafelman have two different identities while at the same time partaking in the general Berber culture.

This means that the Berber cultural community exists but the real relational mechanisms that make common cultural dynamics possible are seen through each tribe's identity. This idea is made clear if one considers the dialectical relationship that Aswaw, leader of the Ait Yafelman tribe, establishes between the general Berber culture and individual tribes. Speak- 
ing to the Far'oun, who are expelled from their homeland by the conquering Arabs, Aswaw uses the river Oum-er-Bia metaphorically as a human community that cannot survive without the contributions of its tributaries. Through this fluvial analogy, Aswaw explains the interrelationship that regulates the life of the source of the main river and its tributaries. $\mathrm{He}$ declares:

Yes, but it [the source] cannot survive very long with nothing but its springs. Its tributaries nourish it, numerous streams and rivers that cannot survive by themselves either. Each one of them contributes its water, and if a single stream ceases to contribute its water, the river runs dry. Mother Spring, 32

If, by analogy, the river becomes a human community, then the desire to live together that underlines any topos of culture is considered in terms of an obligatory sharing by its members. It is, therefore, significant that Aswaw does not select certain cultural traits to the detriment of others but emphasizes the dialectical bonding of differences that transforms the cultural space into a functional community. Seen in this light, the Berber culture comes alive through the vitality of individual tribal identities.

If, on a larger scale, the Berber culture translates itself through a network of tribal values, the same dialectical principle operates within the Ait Yafelman tribe itself. As a single community, the Ait Yafelman tribe thrives on the exchange of abilities of its individual members. Aswaw clearly explains this logic of cultural co-existence to the Far'oun tribe:

It is the same with us, the Ait Yafelman, the Sons of the Water. We are not a single family, but many. Nevertheless, we form a single community. Each one of us brings his own capacities, his own life experience, his honor and ability in what he knows to do with his hands and what to say with his tongue. Mother Spring, 32

Through this declaration, we can observe that the location of culture becomes a site of different identities in what Jean-Luc Nancy (1996) characterizes pertinently as "l' être singulier pluriel," "the singular plural being." In Chraïbi's novel, cultural commonality becomes in fact shared identity differences. For this writer, the Self, therefore, becomes meaningless without being related to the constituent alterities that inform it. Seeking to reveal the dynamic plurality of the Ait Yafelman culture through Aswaw, Chraibi demonstrates that the totality of culture cannot be expressed without the Other(s) that create(s) the whole. In Mother Spring, the Other forms an integral component of the Self in what becomes an inseparable dialectic principle of the identity of the Ait Yafelman tribe. It is through 
this principle that the discursive plurality of cultural dynamism ceases to be a fragmentary relativism but a site where different identities enter into communication with each other.

However, through these shared differences, the culture of the Self is lived in harmony as well in contestation. That is why agonistic interelationship also characterizes the Berber cultural site in Mother Spring. This space, apparently harmonized through identical cultural traits, is treated in terms of historical conflicts by Far'oun the One-Eyed, Hineb's father and Aswaw's future father-in-law. In order to narrate the history of the Berbers to his daughter, Far'oun the One-Eyed, maimed by the Arabs, goes far back in time to reveal the fratricidal tribal wars that have preceded the arrival of the Arabs. He declares to his daughter Hineb:

Add to the countless wars, internal and intertribal! They date from the beginning of time, but they took place between brothers, over a woman, a harvest, some cattle, and often for no reason other than the urge to kill. That was the way it was, that was part of man.... The vanquished tribe submitted itself to the conquerors, became their vassal, bore the yoke, and lived in drudgery, until such time as history freed them once again-or were suzerain in their turn. That happened throughout the centuries, wherever there were communities of Imazighen, plains and valleys. That was the law. Mother Spring, 27-8

This historical narrative transmitted orally by a fugitive Berber at the time of the Arabization of the Maghreb becomes a re-writing of the past almost always idealized exaggeratively by writers driven by a desire to treat precolonial Africa as a topos of non-violence. Chased away from his native land, Far'oun is an Other of the Arab conquerors. His otherness, however, constitutes only one dimension of the historical alterities contained within his own Berber community through the marginalizations and the dominations brought about by tribal wars. This otherness within the space of the Self is further evidenced by the inferior situation of the Far'oun when they seek refuge from the Aït Yafelman. Although they are all Berbers, the fact that the Far'oun are seeking hospitality from the Aït Yafelman demands a lowering of their social status. In fact, the Far'oun are later assimilated by the Ait Yafelman, a fact that is accomplished by the marriage between Aswaw and Hineb, the only surviving female figure in the Far'oun tribe. This means that marginalization does not only happen when a conquering "outsider" vanquishes an indigenous people but also occurs through alterities caused by cultural practices found within the Berber community itself. 
This conflictual co-existence of Berbers makes one understand the ambivalence that Homi Bhabha considers as the very nature of cultural community. Revealed through hatred as well as through love, this ambivalence makes it impossible to homogenize cultural space. In fact, as the critic re-affirms pertinently, it reveals the otherness of the Self and shakes up the apparent stability of the communal identity of the same people:

Once the liminality of the nation-space is established, and its "difference" is turned from the boundary "outside" to its finitude "within," the threat of cultural difference is no longer the problem of "other" people. It becomes a question of the otherness of the people-as-one. Nation and Narration, 301

It is this "otherness of the people-as-one" that is exemplified through Far'oun's narration of Berber tribal wars, the rejection of the Far'oun by other Berbers when they are homeless, and their eventual domination by the Ait Yafelman.

Julia Kristeva re-examines this agonistic nature of culture and identity at the level of the individual for, according to her, we are all "strangers to ourselves":

The image of hatred and of the other, a foreigner is neither the romantic victim of our clannish indolence nor the intruder responsible for all the ills of the polis.... Strangely, the foreigner lives within us: he is the hidden face of our identity, the space that wrecks our abode, the time in which understanding and affinity founder. By recognizing him within ourselves, we are spared detesting him in himself. A symptom that precisely turns "we" into a problem, perhaps makes it impossible, the foreigner comes in when the consciousness of my difference arises, and he disappears when we all acknowledge ourselves as foreigners, unamenable to bonds and communities. Strangers to Ourselves, 1

Within the cultural space of the Ait Yafelman, it is at the time of the Arabization of the Maghreb that the apparent harmonious co-existence of the tribe becomes problematic. This is seen in the confrontation between Aswaw and the Council of Elders who consider the past as the sole solution to the eventual assimilation of their tribe by the Arabs. Aswaw, a visionary marginalized within his own tribe, sees the danger of this total dependence on the past, filled with verbal promises but devoid of any practical solution to the present cultural problem:

How often he had foreseen the catastrophe of words! He knows that many tribes, once vigorous, broke up because they rested 
on their past glories. And not simply tribes, but whole peoples: Romans, Phoenicians, Greeks, and Egyptians . . . whose bards now tell the story, truly both beautiful and sad. Mother Spring, 49

Aswaw embodies the "consciousness of difference" of Aït Yafelman community and symbolizes the border that questions traditions and provokes the transformation needed for the survival of his people:

The earth is reborn every spring-time, the river also, the Ocean. Why not us? We have lived for ourselves for ages and ages inside our own territory to the point where we have impoverished ourselves in ideas. We need to renew ourselves. What could be our death is going to give us new life. Mother Spring, 73

Aswaw adopts a policy of cultural openness because he knows that his tribe cannot live through the Arabic conquest without a certain amount of compromise of their identity. But by preserving the life of his tribe through this policy, Aswaw also recognizes the cultural transformation that the entire identity of his tribe will undergo. Yassin, the Arabic name that he gives his son, the dispersion of his people and their endless journey across the Maghreb are the indications of the impossible return to their origin. By becoming the muezzin of the larger islamic community, Aswaw himself becomes the symbol of the accomplished version of cultural hybridity.

Converted to Islam but conscious of his Berber identity, Aswaw is in fact a personality that lives his own cultural ambiguities on a daily basis. $\mathrm{He}$ is not, however, one of those heroes who fight against cultural alienation for he accepts otherness of the self as a fact of life. On the narrative level, Aswaw the Berber, who has become Imam Filani, tells his own story. He interrogates himself constantly on his identity that has not only become a long endless journey but also a dialectic wrangling between the Berber and the Muslim within him:

Who will win? The Berber or the Muslim? Me or Me? The steps are steep and high. I climb them one by one with difficulty. A very ancient patience, coming from the depths of the ages and bearing its fruit in the centuries to come, climbs with me. Who will be the first to the top? The believer or the pagan? The two of us will give the cry for prayer with the same faith.... Allah will judge and so will Mother Spring. Mother Spring, 117

This reciprocity that regulates the existential duality of Aswaw's identity further demonstrates the ambivalence of co-existence of identities in the 
cultural space. It is in the light of this ambivalence that Aswaw's treason of Oqba, the Bedouin leader of the Arabs, whom he claims to love "with the madness of forebears" (Mother Spring 112) while hating him at the same time, can be understood. Aswaw's action can be likened to that of the Berbers who kill each other within their own cultural site. If the Berbers kill each other and the Afriks, Berbers too, repudiate their own brothers for an eventual economic gain, then one can consider Aswaw's action as an element of the ambiguities underlining the co-existence of identities. These agonistic historical relationships that regulate cultural performance in Mother Spring make it impossible to represent Maghrebian culture with reference to a simple past and identity as declared pertinently by Danielle Marx-Scouras:

By writing about the origins of Islam in the Maghreb, Chraïbi provides a genealogical perspective that restores the complexity of struggles and competing interests to the image of a reality from which oversimplified myths of origin spring. This is the reality that nationalists and fundamentalists often seek to deny, as if the Maghreb were not a site where Africa, Europe, and the Middle East intersect-a potential stage for the inter-play of cultural diversity, ethnic pluralism, and multilingualism. "Literature of Departure," 141

This representation of plural Maghreb is the main idea of the first part of Mother Spring, which in fact is its epilogue. Situated in the $20^{\text {th }}$ century, this section of the novel shows islamized Berbers living alongside Arabs. The transformation of identity that will change the life of the Ait Yafelman tribe at the time of the Arabization of the Maghreb is accomplished thirteen centuries after Aswaw. The tribe, now completely Muslim, lives not on the banks of the river Mother Spring but in a mountaineous and desert region. The tribe has, therefore, become a diaspora community as evidenced through their geographic displacement as well as their identity transformation. Raho Ait Yafelman has become the modern avatar of Aswaw since, like his ancestor before him, he has to confront the problem of another cultural assimilation of his now Berbero-Muslim tribe, this time western.

It is significant that Chraibi demonstrates the impact of western values not only on Raho, the islamized Berber, but also on the Arabs themselves. Chraibi seems to show that within the present Maghrebian space, the effects of alienation caused by western culture have become a force to reckon with by all existing anterior cultures. The Arabization of the Maghreb that has caused the marginalization of Berber culture and identity is in fact 
compared to French colonization that is in the process of westernizing both Arabs and Berbers:

What year could it be among the Arabs, according to the Hegira? No doubt they did not know themselves. Up to now, they counted dates and money in the manner of the Zeropeans. Like the Arabs, Raho was a Muslim at heart if not in thinking. He had learned their language, or at least their common vocabulary (and a few words of French) so that he could go through his human existence without too much poverty, racket, or misunderstanding. Mother Spring, 3

The Westernization of indigenous cultures is also seen by the presence of city government officials who try to give new individual labels to a BerberoMuslim community that thrives on its communal identity. Within this community, Raho Aït Yafelman comes to the bitter realization that his cultural community does not have the necessary tools at its disposal to resist the powerful process of post-colonial acculturation:

Raho knew very well that the resources of the the human soul were inexhaustible, and that he and his had used all sorts of artifices and subterfuges one year after another to escape the law of the greatest number and to preserve their peace. But he also knew full well that those were nothing more than tricks of children, and that inevitably there would come a day when all these mountains would be erazed, and then where would their refuge be? Mother Spring, 17

Contrarily to the Arabization of the Maghreb that is effected through wars, it is now a question of the onslaught of "science itself (this jewel of the Occident)" (Mother Spring 17). Each historical moment has its own way of cultural transformation, and the condition of modernity that hangs over the tribal community is the presence of the city officials whose acculturation policy will eventually lead to the eradication and dispersal of the Ait Yafelman community. In fact, the transfer of western culture which will effect this change of identity is done not by the West itself but by alreadyassimilated indigenous people.

By insisting on this perpetual cultural transformation, Chraibi makes history and time two important components of the formation of identity. In Mother Spring, he reminds us that to situate culture at one single moment and to talk about identity without the necessary temporal transformations is to situate oneself in an empty time. It is only through the historical dimensions of culture that the dialectical voices of others that constitute communal identity can be captured. In the Maghrebian cultural space, the 
voice of the Other is first of all depicted through identity differences among the Berbers themselves. This voice of the Other in the discourse of the Self reveals itself in the Arabization of Berbers. It is this dialectic of the Self and the Other that is finally seen in the Westernization of both Arabs and Berbers in the post-colonial Maghrebian space.

University of Cincinnati 


\section{Works Cited}

Bhabha, Homi. The Location of Culture. London: Routledge, 1994.

-. Nation and Narration. London: Routledge, 1990.

Chraibi, Driss. Mother Spring. Trans. Hugh Harter. Washington D.C: Three Continents, 1989.

Kristeva, Julia. Strangers to Ourselves. Trans. Leon S. Roudiez. New York: Columbia University Press, 1991.

Marx-Scouras, Danielle. "Literature of Departure: The Cross-Cultural Writing of Driss Chraïbi," Research In African Literatures 23.2 (1992): 131-44.

Nancy, Jean-Luc. Etre singulier pluriel. Paris: Galilee, 1996. 